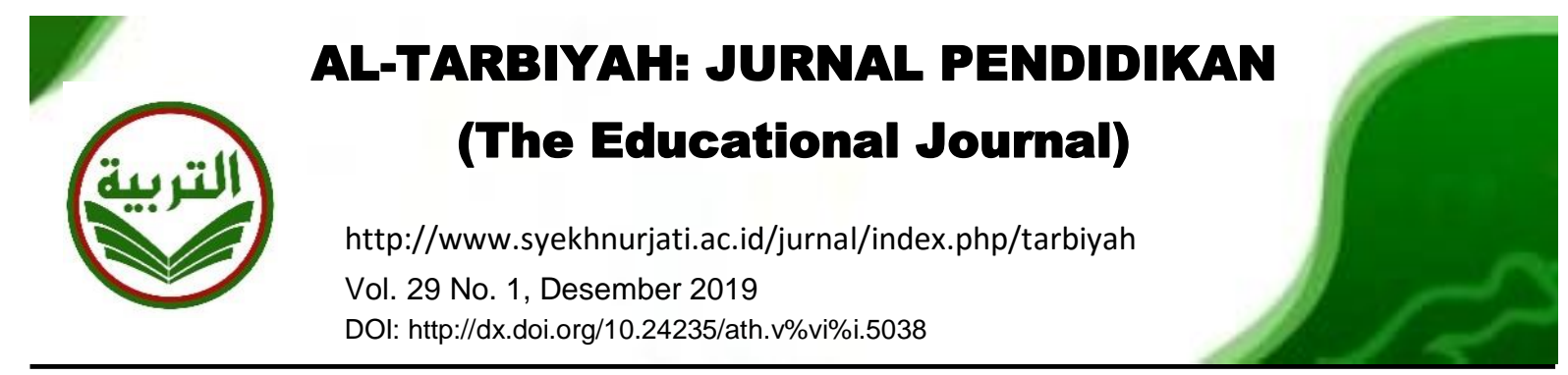

\title{
STUDI KASUS GERAKAN LITERASI SEKOLAH DI KABUPATEN TEGAL KARASIDENAN PEKALONGAN
}

\author{
Shintia Dwi Alika ${ }^{1)}$, Veni Nurpadillah' ${ }^{2)}$, dan Kurnia Dewi Nurfadilah ${ }^{3)}$ \\ ${ }^{1}$ Teknik Informatika, Institut Teknologi Telkom Purwokerto \\ ${ }^{2}$ Pendidikan Bahasa Indonesia, IAIN Syekh Nurjati Cirebon \\ ${ }^{3}$ Pendidikan Bahasa Indonesia, Pascasarjana Universitas Negeri Semarang \\ e-mail: shintia@ittelkom-pwt.ac.id
}

\begin{abstract}
Abstrak
Kemampuan literasi yang tinggi dapat mendorong perkembangan kearah tingkatan yang lebih tinggi lagi. Oleh karena itu, banyak negara khususnya yang sedang membangun dan berkembang menjadikan literasi sebagai agenda utama pembangunan yang banyak menelan biaya. Signifikasi literasi ternyata belum mampu memberikan kesadaran bagi berbagai pihak yang berkecimpung dalam dunia pendidikan untuk segera bergegas meningkatan penguasaan literasi keilmuan masyarakatnya. Hal tersebut mendorong peneliti untuk melihat dan menganalisis kegiatan literasi di lingkungan Sekolah Menengah Atas di Karesidenan Pekalongan, dengan menggunakan metode penelitian kualitatif dan fokus utama penelitian ini adalah gerakan literasi sekolah yang dilakukan di SMA Negeri 2 Slawi yang berada di Kabupaten Tegal. Penelitian melibatkan 50 siswa kelas XII SMA, yang terdiri dari 25 siswa kelas XII IPA dan 25 siswa kelas XII IPS.Sumber data penelitian ini adalah dokumentasi, hasil angket dan persepsi guru dan siswa. Berdasarkan hasil observasi di SMA Negeri 2 Slawi, sekolah tersebut belum melaksanakan kegiatan literasi sekolah. Karena tidak semua siswa dan gurunya mengetahui gerakan tersebut. Akan tetapi minat membaca dan menulis siswanya sudah cukup baik.
\end{abstract}

Kata Kunci $\quad$ : Gerakan Literasi Sekolah, Literasi Keilmuan, Studi Kasus

\begin{abstract}
High literacy skills can encourage development towards higher levels. Therefore, many countries, especially those that are growing and developing, make literacy the main agenda of development that costs a lot. The significance of literacy has not been able to provide awareness for various parties involved in the world of education to immediately rush to increase the mastery of scientific literacy of their society. This encourages researchers to see and analyze literacy activities in high school environment in Pekalongan countSy, using qualitative research methods and the main focus of this research is the school literacy movement carried out in 2 Slawi Public High Schools in Tegal Regency. This research involved 50 senior high school students of class XII, consisting of 25 students of class XII IPA and 25 students of class XII IPS.
\end{abstract}


The data sources of this study were documentation, questionnaire results and perceptions of teachers and students. Based on the results of observations in SMA 2 Slawi, the school has not implemented school literacy activities. Because not all students and teachers know the movement however students interest in reading and writing students is quite good.

Keywords: School Literacy Movement, Scientific Literacy, Case Study

\section{PENDAHULUAN}

Perkembangan ilmu pengetahuan dan teknologi yang berlangsung saat ini berkembang dengan sangat cepat dan berkompetisi di segala bidang dengan sangat ketat yang mutlak memerlukan penguasaan literasi, terutama literasi kelimuan yang memadai. Kondisi ini memungkinkan seseorang akan tertinggal dan kalah dalam kompetisi di berbagai bidang. Sebaliknya, kemampuan literasi (keilmuan) yang tinggi dapat pula mendorong perkembangan tersebut kearah tingkatan yang lebih tinggi lagi. Oleh karena itu, banyak negara khususnya yang sedang membangun dan berkembang menjadikan literasi sebagai agenda utama pembangunan yang banyak menelan biaya. Menurut Lerner (1988) kemampuan membaca merupakan dasar untuk menguasai berbagai bidang studi. Jika anak pada usia sekolah permulaan tidak segera memiliki kemampuan membaca, maka ia akan mengalami banyak kesulitan dalam mempelajari berbagai bidang studi pada kelas-kelas berikutnya.

Pendidikan dan kemampuan literasi adalah dua hal yang sangat penting dalam hidup kita. Kemajuan suatu negara secara langsung tergantung pada tingkat melek huruf di negara tersebut. Orang berpendidikan diharapkan untuk melakukan tugasnya dengan baik. Secara historis, Menurut Tarwotjo (1994) produk dari aktivitas Literasi berupa tulisan, adalah sebuah warisan intelektual yang tidak akan kita temukan di zaman prasejarah. Dengan kata lain, apabila tidak ada tulisan, sama saja kita berada di zaman prasejarah. Tulisan merupakan bentuk rekaman sejarah yang dapat diwariskan dari generari ke generasi, bahkan hingga berabad-abad lamanya. Sejalan dengan pendapat Kern (2000) literasi adalah praktik-praktik menginterpretasikan makna teks melalui situasi sosial, dan historis, serta kultural. Dari beberapa paparan tersebut dapat disimpulkan literasi merupakan kemampuan dalam mengakses, memahami, dan menggunakan informasi sebagai proses berpikir, membaca, intrepretasi kemudian diwujudkan berupa tindakan menulis atau berbicara.

Signifikasi literasi (kelimuan) tersebut ternyata belum mampu memberikan kesadaran bagi berbagai pihak yang berkecimpung dalam dunia pendidikan untuk segera bergegas meningkatan penguasaan literasi keilmuan masyarakatnya. Hal ini diperkuat dengan kenyataan bahwa kemampuan literasi masyarakat Indonesia tergolong masih rendah. Terkait dengan hal ini, Firdaus (2004) mengemukakan bahwa literasi bangsa Indonesia lebih rendah dari bangsa Barat, bahkan dengan taraf membaca pun masih rendah. Banyak manusia yang bisa membaca namun lebih memilih tidak membaca. Begitupun juga banyak manusia yang bisa membaca namun tidak minat untuk menulis atau menghasilkan tulisan. Hal ini dipicu karena rendahnya minat 
menulis masyarakat teutama pelajar. Mereka takut untuk memulai menulis karena takut tulisannya tidak bagus atau tidak ada yang membaca dan memuji tulisannya.

Purwanto (2007) mengemukakan bahwa faktor penyebab rendah kemampuan membaca adalah tradisi kelisanan yang masih mengakar di masyarakat. Masyarakat tempo dulu lebih memanjakan tradisi lisan daripada tradisi literasi. Padahal sumber manusia yang literat merupakan asset yang paling signifikan bagi negara manapun di dunia (Ambigapati, 1999). Selain itu, sistem pendidikan tingkat rendah hingga tinggi masih kurang memberi porsi lebih bagi tradisi literasi. Bahkan, sebagai kaum intelektual yang menjadi penyumbang terbesar dalam kultur literasi di Indonesia, siswa lebih suka mendapat informasi yang "dibacakan" dan berlaku sebagai "pembaca pasif" yang dengan tenang menguyah-renyah segala persepsi yang dikemukakan oleh televisi. Belum lagi budaya nongkrong di kafe, mal, dan nonton film makin meminggirkan mahasiswa dari tradisi literasi (Wulansari, 2011).

Wells (1987, 111) menyebutkan bahwa terdapat empat tingkatan literasi, yaitu performative, functional, informational, dan epistemic. Orang yang tingkat literasinya beradapada tingkat performatif, ia mampu membaca dan menulis, serta berbicara dengansimbolsimbol yang digunakan (bahasa). Pada tingkat functional orang diharapkan dapat menggunakan bahasa untuk memenuhi kehidupan sehari-hari seperti membaca buku manual. Pada tingkat informational orang diharapkan dapat mengakses pengetahuan dengan bahasa. Sementara pada tingkat epistemic orang dapat mentransformasikan pengetahuan dalam bahasa. Dengan demikian tingkatan literasi dimulai dari tingkatan paling bawah yaitu performative, functional, informational, dan epistemic.

Berdasarkan hal tersebut pembentukan generasi literat dapat dijadikan sebagai jembatan menuju masyarakat makmur yang kritis dan peduli. Kritis terhadap segala informasi yang diterima sehingga tidak beraksi secara emosional; dan peduli terhadap lingkungan sekitar. Hingga pada akhirnya, melalui kemampuan literasi diharapkan pembentukan generasi literat dapat terbentuk dan berdampak pada peningkatan mutu pendidikan secara keseluruhan. Tujuan penelitian ini untuk mengetahui gerakan literasi sekolah siswa kelas XII SMA Negeri 2 Slawi.

\section{METODE PENELITIAN}

Metode penelitian merupakan faktor yang sangat penting dalam kegiatan penelitian, karena ketepatan dalam menentukan metode penelitian yang dilaksanakan akan memberikan hasil yang baik dan dapat dipertanggung jawabkan. Metode penelitian pada dasarnya merupakan cara ilmiah untuk mendapatkan data dengan tujuan dan kegunaan tertentu (Sugiyono, 2010).

Metode yang digunakan dalam penelitian ini adalah metode penelitian kualitatif. Menurut Bogdan dan Taylor (dalam Moleong, 2007) penelitian kualitatif merupakan prosedur penelitian yang menghasilkan data deskriptif, berupa katakata yang terucapkan secara lisan dan tertulis serta perilaku orang. Penelitian dengan pendekatan kualitatif selalu berakar alamiah dan sumber datanya berkonteks sewajarnya. Sejalan dengan pendapat Tanzeh (2011) penelitian kualitatif yakni penelitian yang dimaksudkan untuk 
mengungkap gejala holistik-kontekstual melalui pengumpulan data dari latar alami sebagai sumber langsung dengan instrumen kunci peneliti itu sendiri. Dalam metode kualitatif, penelitian sebagai instrumen utama dan dalam penelitiannya lebih mengutamakan data langsung yang hasilnya disepakati bersama antara peneliti dan reponden.

Fokus utama penelitian ini adalah gerakan literasi sekolah yang dilakukan di SMA Negeri 2 Slawi yang berada di Kabupaten Tegal. Pada 50 siswa kelas XII SMA, yang terdiri dari 25 siswa kelas XII IPA dan 25 siswa kelas XII IPS. Sumber data penelitian ini adalah dokumentasi, hasil angket dan persepsi guru dan siswa. Teknik pengumpulan data merupakan langkah yang paling utama dalam penelitian, karena tujuan utama dari penelitian adalah mendapatkan data. Tanpa mengetahui teknik pengumpulan data, maka peneliti tidak akan mendapatkan data yang memenuhi standar data yang ditetapkan.

Untuk memperoleh data primer dalam penelitian ini, digunakan pedoman data berupa observasi, angket, wawancara. Instrumen-instrumen inilah yang digunakan untuk memperoleh data tentang gerakan literasi sekolah yang dilakukan di SMA Negeri 2 Slawi. Data-data di atas dalam penelitian ini diperoleh dengan cara mengumpulkan langsung dari lapangan melalui nontes dan teknik tes. Teknik yang digunakan di antaranya angket, pengamatan langsung/lapangan, dan wawancara. Penelitian hasil angket siswa tentang gerakan literasi sekolah ini menggunakan instrumen penelitian berupa pedoman observasi.
Analisis yang digunakan dalam penelitian ini dilakukan dengan mengikuti logika pendekatan kualitatif, yaitu melalui pengumpulan data yang bersifat kualitatif untuk disajikan dan diadakan reduksi data yang selanjutnya diambil simpulan. Teknik analisis data yang digunakan adalah model analisis interaksi, yaitu menghubungkan antara kategori dengan subkategori untuk kemudian dicari pola-polanya. Ulfatin (2015) menegaskan dalam penelitian kualitatif, manusialah yang bertindak sebagai instrumen kunci atau alat pengumpul data utama. Peneliti sendiri bertindak sebagai instrumen kunci. Peneliti sebagai alat atau instrumen kunci dalam penelitian, sehingga kehadirannya pada latar penelitian mutlak dilakukan.

\section{HASIL DAN PEMBAHASAN}

SMA Negeri 2 Slawi merupakan salah satu sekolah yang berada dalam lingkup karesidenan Pekalongan. Berdasarkan hasil observasi di sekolah tersebut, pada dasarnya siswa dan guru telah mengetahui tentang gerakan literasi atau budaya membaca dan menulis. Hasil penyebaran angket dan wawancara terhadap siswa dan guru mengenai persepsinya terhadap gerakan budaya membaca dan menulis akan dipaparkan sebagai berikut. 
Tabel 1. Angket Persepsi Siswa

\begin{tabular}{|c|c|c|c|c|}
\hline No. & Aspek & $\begin{array}{c}\text { Pilihan } \\
\text { Jawaban }\end{array}$ & $\begin{array}{c}\text { Intensitas } \\
\text { Jawaban }\end{array}$ & Alasan \\
\hline \multirow[t]{3}{*}{1.} & \multirow[t]{3}{*}{$\begin{array}{l}\text { Pembiasaan Budaya } \\
\text { Literasi di sekolah }\end{array}$} & Ada & 44 & \\
\hline & & Tidak & 174 & \\
\hline & & Lainnya & 32 & \\
\hline \multirow[t]{4}{*}{2.} & \multirow[t]{4}{*}{$\begin{array}{l}\text { Pengembangan Budaya } \\
\text { Literasi di sekolah }\end{array}$} & Ada & 90 & \\
\hline & & Tidak & 113 & \\
\hline & & Tidak Tahu & 47 & \\
\hline & & Lainnya & 2 & \\
\hline \multirow[t]{4}{*}{3.} & \multirow{4}{*}{$\begin{array}{l}\text { Budaya Literasi dalam } \\
\text { Pebelajaran Bahasa } \\
\text { Indonesia }\end{array}$} & Ada & 98 & \\
\hline & & Tidak & 112 & \\
\hline & & Tidak tahu & 40 & \\
\hline & & Lainnya & - & \\
\hline
\end{tabular}

\section{Deskripsi Persepsi Siswa Kelas XII} SMA N 2 Slawi terhadap Budaya Literasi Sekolah

Agar sekolah mampu menjadi garis depan dalam pengembangan budaya literasi, de Beers \& Mason (2009) menyampaikan beberapa strategi untuk menciptakan budaya literasi yang positif di sekolah yang meliputi tiga aspek, yaitu pembiasaan budaya literasi sekolah, pengembangan budaya literasi sekolah, dan penerapan budaya literasi sekolah dalam mata pelajaran Bahasa Indonesia. Berikut merupakan pemaparan dari ketiga aspek tersebut menurut de Beers \& Mason (2009).

\section{a. Pembiasaan Budaya Literasi Sekolah}

Aspek yang pertama meliputi gambaran awal terhadap program literasi sekolah yang sudah dijalankan selama satu semester ini. Program literasi sekolah dapat berjalan dengan lancar apabila semua warga sekolah terbiasa berliterasi atau membudayakan membaca dan menulis. Aspek pembiasaan dijabarkan melalui 5 indikator, yaitu pelaksanaan literasi sebelum pembelajaran, keikutsertaan guru, kepala sekolah, dan staf karyawan dalam kegiatan literasi, buku penunjang, kesediaan majalah dinding sebagai hasil karya siswa, kenyamanan siswa, tempat untuk berliterasi dan kegiatan pendukung budaya literasi sekolah. Jumlah keseluruhan data yang didapatkan peneliti dan layak untuk dianalisis sebanyak 50 siswa. Gambaran tentang persepsi siswa terhadap budaya literasi sekolah dapat dilihat dalam tabel berikut ini. 
Tabel 2. Persepsi Siswa terhadap Budaya Literasi Sekolah

\begin{tabular}{|c|c|c|c|c|}
\hline No. & Sub Aspek & $\begin{array}{l}\text { Pilihan } \\
\text { Jawaban }\end{array}$ & $\begin{array}{c}\text { Intensitas } \\
\text { Jawaban }\end{array}$ & Alasan \\
\hline \multirow[t]{3}{*}{1.} & \multirow{3}{*}{$\begin{array}{l}\text { Kegiatan } 15 \text { menit } \\
\text { membaca yang dilakukan } \\
\text { setiap hari di sekolahmu } \\
\text { sebelum pembelajaran }\end{array}$} & Ada & 13 & \\
\hline & & Tidak & 32 & $\begin{array}{l}\text { Di sekolah belum diberlakukan } \\
\text { kegiatan membaca } 15 \text { menit sebelum } \\
\text { pembelajaran. }\end{array}$ \\
\hline & & Lainnya & 5 & \\
\hline \multirow[t]{3}{*}{2.} & \multirow{3}{*}{$\begin{array}{l}\text { Memiliki jurnal/catatan } \\
\text { harian tentang buku-buku } \\
\text { yang dibaca setiap } \\
\text { harinya }\end{array}$} & Ada & 6 & \\
\hline & & Tidak & 43 & $\begin{array}{l}\text { Karena tidak setiap hari selalu } \\
\text { membaca dan mencatat. }\end{array}$ \\
\hline & & Lainnya & 1 & \\
\hline \multirow[t]{4}{*}{3.} & \multirow{4}{*}{$\begin{array}{l}\text { Guru/kepala } \\
\text { sekolah/tenaga } \\
\text { kependidikan di } \\
\text { sekolahmu juga ikut } \\
\text { melakukan aktivitas } \\
\text { membaca }\end{array}$} & Ada & 11 & \\
\hline & & Tidak & 30 & Karena tidak ada kegiatan seperti itu. \\
\hline & & Tidak tahu & 7 & \\
\hline & & Lainnya & 2 & \\
\hline \multirow[t]{3}{*}{4.} & \multirow{3}{*}{$\begin{array}{l}\text { Terdapat majalah dinding } \\
\text { hasil karyamu dan teman- } \\
\text { teman }\end{array}$} & Ada & 6 & \\
\hline & & Tidak & 41 & $\begin{array}{l}\text { Karena sudah ada mading yang } \\
\text { dikelola sekolah. }\end{array}$ \\
\hline & & Lainnya & 3 & \\
\hline \multirow[t]{3}{*}{5.} & \multirow{3}{*}{$\begin{array}{l}\text { Kegiatan yang } \\
\text { mendukung budaya } \\
\text { membaca di sekolah }\end{array}$} & Ada & 9 & \\
\hline & & Tidak & 26 & $\begin{array}{l}\text { Karena kami ke perpustakaan pada } \\
\text { saat-saat tertentu. }\end{array}$ \\
\hline & & Lainnya & 15 & \\
\hline
\end{tabular}

Berdasarkan tabel tersebut, kegiatan 15 menit membaca sebelum pembelajaran tidak dilakukan oleh pihak sekolah. Hal ini dibuktikan dari intensitas jawaban siswa pada angket yang menyatakan 32 siswa menjawab tidak adanya kegiatan 15 menit membaca sebelum pembelajaran. Sisanya ada 13 siswa yang menjawab "ada" dan 5 siswa menjawab "lainnya".
Selanjutnya untuk sub aspek yang menyatakan memiliki jurnal/catatan harian tentang buku-buku yang dibaca setiap harinya ada 43 siswa yang menjawab "tidak" alasannya karena tidak setiap hari selalu membaca dan mencatat. Sisanya ada 6 siswa yang menjawab "ada" dan 1 siswa menjawab "lainnya". 

45-60

Untuk sub aspek yang menyatakan guru/kepala sekolah/tenaga kependidikan di sekolah juga ikut melakukan aktivitas membaca ada 30 siswa menjawab "tidak" karena pada kenyataannya guru/kepsek/tenaga kependidikan tidak ikut berpartisipasi dalam hal itu. Sisanya 11 siswa menjawab "ada", 7 siswa menjawab "tidak tahu" dan 2 siswa menjawab "lainnya".

Sub aspek yang menyatakan bahwa terdapat majalah dinding hasil karya siswa ada 41 siswa yang menjawab "tidak" alasannya karena sudah ada mading yang dikelola sekolah. Sisanya 6 siswa menjawab "ada" dan 3 siswa menjawab "lainnya".

Untuk sub aspek yang terakhir yaitu kegiatan yang mendukung budaya membaca di sekolah 26 siswa menjawab "tidak ada" alasannya karena mereka ke perpustakaan pada saat-saat tertentu saja. Sisanya 9 siswa menjawab "ada" dan 15 siswa menjawab "lainnya".

\section{b. Pengembangan Budaya Literasi di Sekolah}

Kegiatan literasi pada tahap ini bertujuan mengembangkan kemampuan memahami bacaan dan mengaitkannya dengan pengalaman pribadi, berpikir kritis, dan mengolah kemampuan komunikasi secara kreatif melalui kegiatan menanggapi bacaan pengayaan (Anderson \& Krathwol, 2001).

Pada bagian pengembangan budaya literasi di sekolah terdapat 5 sub aspek, yaitu (1) memiliki catatan komentar terhadap buku-buku yang sudah dibaca, (2) catatan komentar terhadap buku-buku yang dibaca dibahas oleh semua guru mata pelajaran, (3) tugas merangkum buku-buku yang sudah dibaca, (4) kegiatan penambahan/pembaruan koleksi buku fiksi di perpustakaan, (4) sudut baca di tiap kelas, (5) area baca di sekolah, dan (6) penghargaan/hadiah dari sekolah/guru atas jumlah buku yang sudah mereka baca. Dari 50 siswa, berikut merupakan rangkuman hasil jawaban siswa beserta analisisnya.

Tabel 3. Rangkuman Hasil Jawaban Siswa

\begin{tabular}{|c|c|c|c|c|}
\hline No. & Sub Aspek & $\begin{array}{l}\text { Pilihan } \\
\text { Jawaban }\end{array}$ & $\begin{array}{c}\text { Intensitas } \\
\text { Jawaban }\end{array}$ & Alasan \\
\hline \multirow[t]{4}{*}{1.} & \multirow{4}{*}{$\begin{array}{l}\text { Memiliki catatan komentar terhadap } \\
\text { buku-buku yang sudah dibaca }\end{array}$} & Ada & 2 & \\
\hline & & Tidak & 42 & $\begin{array}{l}\text { Bingung untuk } \\
\text { mengungkapkannya. }\end{array}$ \\
\hline & & Tidak Tahu & 6 & \\
\hline & & Lainnya & - & \\
\hline \multirow[t]{2}{*}{2.} & \multirow{2}{*}{$\begin{array}{l}\text { Catatan komentar terhadap buku-buku } \\
\text { yang kamu baca dibahas oleh semua } \\
\text { guru mata pelajaran }\end{array}$} & Ada & 2 & \\
\hline & & Tidak & 34 & $\begin{array}{l}\text { Karena tidak pernah ada } \\
\text { kegiatan untuk memberi } \\
\text { komentar buku yang sudah } \\
\text { dibaca. }\end{array}$ \\
\hline
\end{tabular}


Shintia Dwi Alika, Veni Nurpadillah, \& Kurnia Dewi Nurfadilah / AL-TARBIYAH, Vol. 29 No. 1, Desember 2019, 45-60

\begin{tabular}{|c|c|c|c|c|}
\hline & & Tidak Tahu & 14 & \\
\hline \multirow[t]{4}{*}{3.} & $\begin{array}{l}\text { Mendapatkan tugas merangkum buku- } \\
\text { buku yang sudah dibaca }\end{array}$ & Ada & 22 & $\begin{array}{l}\text { Guru pasti menyuruh } \\
\text { siswanya untuk } \\
\text { merangkum. }\end{array}$ \\
\hline & & Tidak & 24 & \\
\hline & & Tidak tahu & 4 & \\
\hline & & Lainnya & - & \\
\hline \multirow[t]{4}{*}{4.} & \multirow{4}{*}{$\begin{array}{l}\text { Kegiatan penambahan/pembaruan } \\
\text { koleksi buku fiksi di perpustakaan, } \\
\text { sudut baca di tiap kelas, dan area baca } \\
\text { di sekolah }\end{array}$} & Ada & 14 & \\
\hline & & Tidak & 14 & \\
\hline & & Tidak tahu & 22 & $\begin{array}{l}\text { Karena tidak pernah ada } \\
\text { informasi mengenai hal } \\
\text { tersebut. }\end{array}$ \\
\hline & & Lainnya & - & \\
\hline \multirow[t]{4}{*}{5.} & \multirow[t]{4}{*}{$\begin{array}{l}\text { Penghargaan/hadiah dari sekolah/guru } \\
\text { atas jumlah buku yang sudah kamu baca }\end{array}$} & Ada & 41 & $\begin{array}{l}\text { Ketika kami berkunjung ke } \\
\text { perpustaakan kemudian } \\
\text { mengisi presensi dan } \\
\text { membaca buku maka akan } \\
\text { diberi penghargaan. }\end{array}$ \\
\hline & & Tidak & 8 & \\
\hline & & Tidak tahu & 1 & \\
\hline & & Lainnya & - & \\
\hline
\end{tabular}

Sub aspek pertama berkaitan dengan siswa memiliki catatan komentar terhadap buku-buku yang sudah dibaca, 42 siswa menjawab "tidak ada" alasannya bingung untuk mengungkapnya. Sisanya 6 siswa menjawab "lainnya" dan 2 siswa menjawab "ada".

Selanjutnya untuk sub aspek catatan komentar terhadap buku-buku yang siswa baca dibahas oleh semua guru mata pelajaran, 34 siswa menjawab "tidak" alasannya karena tidak pernah ada kegiatan untuk memberi komentar buku yang sudah dibaca. Sisanya 14 siswa menjawab "tidak tahu" dan 2 siswa menjawab "ada".
Sub aspek tugas merangkum bukubuku yang sudah dibaca 24 siswa menjawab tidak, 22 siswa menjawab "ada" dengan alasan guru pasti menyuruh siswanya untuk merangkum. Sisanya 4 siswa menjawab "tidak tahu".

Untuk sub aspek kegiatan penambahan/pembaruan koleksi buku fiksi di perpustakaan, sudut baca di tiap kelas, dan area baca di sekolah, 22 siswa menjawab "tidak tahu" dengan alasan karena tidak pernah ada informasi mengenai hal tersebut. Sisanya 14 siswa menjawab "ada" dan 14 siswa lagi menjawab "tidak". 
Sub aspek yang terakhir adalah penghargaan/hadiah dari sekolah/guru atas jumlah buku yang sudah dibaca, 41 siswa menjawab "ada" dengan alasan ketika mereka berkunjung ke perpustaakan kemudian mengisi presensi dan membaca buku maka akan diberi penghargaan. Sisanya 8 siswa menjawab "tidak" dan 1 siswa menjawab "tidak tahu".

\section{c. Penerapan Budaya Literasi Sekolah dalam Mata Pelajaran Bahasa Indonesia}

Pada aspek penerapan budaya literasi dalam pembelajaran bahasa Indonesia terdapat 5 sub aspek, antara lain (1) dalam pembelajaran bahasa Indonesia selalu ada tugas membaca buku/teks nonpelajaran, (2) ada target jumlah buku yang harus dibaca dalam pembelajaran bahasa Indonesia, (3) evaluasi/penilaian yang dilaksanakan oleh guru bahasa Indonesia untuk menilai hasil membaca siswa, (4) tugas menuliskan kembali isi buku yang siswa baca dan (5) hasil tulisan dipajang di majalah dinding sekolah. Dari 50 siswa, berikut merupakan rangkuman hasil jawaban siswa beserta analisisnya.

Tabel 4. Rangkuman Hasil Jawaban Siswa

\begin{tabular}{|c|c|c|c|c|}
\hline No. & Sub Aspek & $\begin{array}{l}\text { Pilihan } \\
\text { Jawaban }\end{array}$ & $\begin{array}{c}\text { Intensitas } \\
\text { Jawaban }\end{array}$ & Alasan \\
\hline \multirow[t]{4}{*}{1.} & \multirow{4}{*}{$\begin{array}{l}\text { Dalam pembelajaran } \\
\text { bahasa Indonesia selalu } \\
\text { ada tugas membaca } \\
\text { buku/teks nonpelajaran }\end{array}$} & Ada & 26 & $\begin{array}{l}\text { Karena sebelum mengerjakan tugas } \\
\text { kami diwajibkan untuk membaca. }\end{array}$ \\
\hline & & Tidak & 22 & \\
\hline & & Tidak Tahu & 2 & \\
\hline & & Lainnya & - & \\
\hline \multirow[t]{4}{*}{2.} & \multirow{4}{*}{$\begin{array}{l}\text { Ada target jumlah buku } \\
\text { yang harus kamu baca } \\
\text { dalam pembelajaran } \\
\text { bahasa Indonesia }\end{array}$} & Ada & 10 & \\
\hline & & Tidak & 34 & Hanya membaca buku paket dan LKS. \\
\hline & & Tidak Tahu & 6 & \\
\hline & & Lainnya & - & \\
\hline \multirow[t]{4}{*}{3.} & \multirow{4}{*}{$\begin{array}{l}\text { Evaluasi/penilaian yang } \\
\text { dilaksanakan oleh guru } \\
\text { bahasa Indonesia untuk } \\
\text { menilai hasil membacamu }\end{array}$} & Ada & 23 & $\begin{array}{l}\text { Jika kami selesai mengerjakan tugas } \\
\text { biasanya akan diminta dibacakan di } \\
\text { depan kelas. }\end{array}$ \\
\hline & & Tidak & 13 & \\
\hline & & Tidak tahu & 14 & \\
\hline & & Lainnya & - & \\
\hline 4. & & Ada & 34 & Biasanya merangkum. \\
\hline
\end{tabular}


Shintia Dwi Alika, Veni Nurpadillah, \& Kurnia Dewi Nurfadilah / AL-TARBIYAH, Vol. 29 No. 1, Desember 2019, 45-60

\begin{tabular}{|c|l|c|c|c|}
\hline \multirow{2}{*}{$\begin{array}{l}\text { kembali isi buku yang } \\
\text { kamu baca }\end{array}$} & Tidak & 14 & \\
\cline { 3 - 5 } & & Tidak tahu & 2 & \\
\cline { 3 - 5 } & $\begin{array}{l}\text { Hasil tulisan dipajang di } \\
\text { majalah dinding sekolah }\end{array}$ & Lainnya & - & \\
\cline { 3 - 5 } & & Ada & 4 & \\
\cline { 3 - 5 } & & Tidak & 31 & $\begin{array}{l}\text { Karena hanya siswa tertentu yang } \\
\text { mau mengirimkan hasil tulisannya. }\end{array}$ \\
\cline { 3 - 5 } & & Tidak tahu & 15 & \\
\cline { 3 - 5 } & & Lainnya & - & \\
\hline
\end{tabular}

Untuk sub aspek yang pertama yaitu dalam pembelajaran bahasa Indonesia selalu ada tugas membaca buku/teks nonpelajaran, 26 siswa menjawab "ada" alasannya karena sebelum mengerjakan tugas siswa diwajibkan untuk membaca. 22 siswa menjawab "tidak" dan sisanya 2 siswa menjawab "tidak tahu".

Selanjutnya untuk sub aspek ada target jumlah buku yang harus kamu baca dalam pembelajaran bahasa Indonesia, 34 siswa menjawab "tidak" dengan alasan hanya membaca LKS dan buku paket. 10 siswa menjawab "ada" dan sisanya 6 siswa menjawab "tidak tahu".

Pada sub aspek evaluasi/penilaian yang dilaksanakan oleh guru bahasa Indonesia untuk menilai hasil membaca siswa, 23 siswa menjawab ada dengan alasan jika mereka selesai mengerjakan tugas biasanya mereka akan diminta membacakannya di depan kelas. 14 siswa menjawab tidak tahu dan sisanya 13 siswa menjawab tidak.
Untuk sub aspek tugas menuliskan kembali isi buku yang siswa baca, 34 siswa menjawab ada dengan alasan biasanya merangkum, 14 siswa menjawab tidak, dan sisanya 2 siswa menjawab tidak tahu.

Sub aspek yang terakhir adalah hasil tulisan dipajang di majalah dinding sekolah, 31 siswa menjawab tidak dengan alasan karena hanya siswa tertentu yang mau mengirimkan hasil tulisannya, 15 siswa menjawab tidak tahu, dan sisanya 4 siswa menjawab ada.

\section{Deskripsi Persepsi Siswa dari Hasil Wawancara}

Persepsi siswa kelas XII SMA Negeri 2 Slawi terhadap budaya literasi sekolah meliputi sepuluh indikator. Berdasarkan hasil wawancara kepada enam siwa, berikut pemaparan dari hasil wawancara tersebut. 


\section{Tabel 5. Hasil Wawancara Siswa}

\begin{tabular}{|c|c|c|}
\hline No & Indikator Pertanyaan & Jawaban Siswa \\
\hline 1 & $\begin{array}{l}\text { Pengetahuan tentang gerakan membaca } \\
15 \text { menit sebelum pembelajaran. }\end{array}$ & $\begin{array}{l}\text { Siswa mengetahu kegiatan tersebut dari guru serta dari } \\
\text { kepala sekolah yang diumumkan dalam upacara hari } \\
\text { senin. }\end{array}$ \\
\hline 2 & $\begin{array}{l}\text { Tanggapan tentang gerakan tersebut dan } \\
\text { penerapannya di kelas. }\end{array}$ & $\begin{array}{l}\text { Setuju, sebagian sudah ada yang menerapkan, tetapi } \\
\text { ada juga yang belum, kegiatan tersebut terkadang } \\
\text { merepotkan. }\end{array}$ \\
\hline 3 & $\begin{array}{l}\text { Dukungan sekolah terhadap gerakan } \\
\text { membaca dan menulis. }\end{array}$ & $\begin{array}{l}\text { Sebagian menjawab mendukung, sebagian tidak } \\
\text { mendukung karena ketersediaan buku-buku yang } \\
\text { menarik kurang diperpustakaan. }\end{array}$ \\
\hline 4 & $\begin{array}{l}\text { Pelaksanaan budaya membaca dan } \\
\text { menulis di sekolah. }\end{array}$ & $\begin{array}{l}\text { Kegiatan tersebut dilaksanakan pada saat } \\
\text { pembelajaran bahasa Indonesia. Terkadamg guru } \\
\text { meminta kami untuk membaca, agar lebih memahami } \\
\text { materi yang sedang dipelajari. }\end{array}$ \\
\hline 5 & $\begin{array}{l}\text { Jumlah buku fiksi yang sudah dibaca } \\
\text { selama satu bulan. }\end{array}$ & 3 buku, 2 buku, 4 buku, \\
\hline 6 & $\begin{array}{l}\text { Guru memberi tugas membaca buku fiksi } \\
\text { dan nonfiksi. }\end{array}$ & $\begin{array}{l}\text { Hanya guru bahasa Indonesia yang memberikan tugas } \\
\text { tersebut, itupun kadang-kadang. }\end{array}$ \\
\hline 7 & $\begin{array}{l}\text { Motivasi yang dilakukan guru dalam } \\
\text { kegiatan membaca dan menulis di dalam } \\
\text { kelas. }\end{array}$ & $\begin{array}{l}\text { Sering memberi nasihat, dan meminta untuk membuat } \\
\text { tulisan yang bagus agar bisa dipajang di majalah } \\
\text { dinding sekolah. }\end{array}$ \\
\hline 8 & $\begin{array}{l}\text { Kesulitan yang dihadapi dalam } \\
\text { mengerjakan tugas menulis. }\end{array}$ & $\begin{array}{l}\text { Kesulitan dalam menyusun kata-kata, serta menulis } \\
\text { dengan menggunakan kaidah yang baik dan benar. }\end{array}$ \\
\hline 9 & $\begin{array}{l}\text { Upaya yang dilakukan dalam mengatasi } \\
\text { kesulitan mengerjakan tugas menulis. }\end{array}$ & $\begin{array}{l}\text { Bertanya kepada guru, mengerjakan berkelompok } \\
\text { dengan teman, dan membaca buku untuk menambah } \\
\text { kosakata. }\end{array}$ \\
\hline 10 & $\begin{array}{l}\text { Fasilitas di sekolah untuk } \\
\text { mengembangkan budaya membaca dan } \\
\text { menulis. }\end{array}$ & $\begin{array}{l}\text { Belum sepenuhnya mendukung untuk } \\
\text { mengembangkan budaya membaca dan menulis. } \\
\text { Seperti perpustakaan misalnya buku-bukunya masih } \\
\text { kurang. }\end{array}$ \\
\hline
\end{tabular}

Pada dasarnya siswa telah mengetahui kegiatan 15 menit membaca tersebut. Siswa mengetahuinya dari guru dan kepala sekolah. Akan tetapi memang SMA Negeri 2 Slawi belum kompak atau sepakat dalam melaksanakan kegiatan tersebut. Sehingga hanya guru bahasa Indonesia yang terkadang melaksanakan kegiatan tersebut.

Akhirnya sebagian siswa beranggapan bahwa sekolah kurang mendukung gerakan lterasi, salah satu 
faktornya fasilitas (sarana dan prasarana) yang mendukung yaitu kurangnya ketersediaan buku-buku bacaan yang menarik diperpustakaan sekolah. Buku adalah salah satu faktor penting untuk mengembangkan gerakan literasi. Selain itu, kegiatan membaca dan menulis pun hanya dilaksanakan pada saat pembelajaran Bahasa Indonesia saja. Akan tetapi, siswasiswa SMA Negeri 2 Slawi pada dasarnya menyukai kegiatan membaca buku fiksi, bahkan ada satu siswa yang membaca empat buku dalam kurun waktu satu bulan.

Guru Bahasa Indonesia, selalu memberikan tugas untuk membaca dan menulis, beliau juga suka memberi nasihat kepada siswanya untuk menulis dengan baik. Hal tersebut dilakukan agar hasil karya tulis siswanya dapat dipublikasikan salah satunya di majalah dinding sekolah. Dalam melaksanakan kegiatan menulis tidaklah mudah, siswa terkadang mengalami kesulitan. Kesulitan yang dihadapi siswa dalam menulis yaitu menyusun kata-kata, menulis dengan menggunakan kaidah yang baik dan benar, dan bahkan menumbuhkan ide tulisan. Untuk menghadapi kesulitan-kesulitan tersebut siswa biasanya akan bertanya kepada guru, berdiskusi dengan temannya, bahkan ada yang membaca buku untuk menambah kosakata.

\section{Deskripsi Persepsi Guru SMAN 2 Slawi Kelas XII terhadap Budaya Literasi Sekolah}

Persepsi guru Bahasa Indonesia kelas XI IPS terhadap budaya literasi sekolah meliputi empat aspek, yaitu (1) pembiasaan budaya literasi sekolah, (2) pengembangan budaya literasi sekolah, (3) penerapan budaya literasi sekolah, (4) serta dalam mata pelajaran bahasa indonesia. Berikut merupakan pemaparan dari keempat aspek tersebut.

\section{a. Pembiasaan Budaya Literasi di Sekolah}

Aspek yang pertama meliputi gambaran awal terhadap program literasi di sekolah. Program literasi di sekolah dapat berjalan dengan lancar apabila semua warga sekolah terbiasa membudayakan membaca dan menulis. Aspek pembiasaan budaya literasi di sekolah tersebut, dijabarkan melalui 12 indikator. Gambaran tentang persepsi guru Bahasa Indonesia terhadap budaya literasi sekolah dapat dilihat dalam tabel berikut ini.

Tabel 6. Persepsi Guru Bahasa Indonesia terhadap Budaya Literasi Sekolah

\begin{tabular}{|c|c|c|c|c|}
\hline No. & Sub Aspek & $\begin{array}{c}\text { Pilihan } \\
\text { Jawaban }\end{array}$ & $\begin{array}{c}\text { Intensitas } \\
\text { Jawaban }\end{array}$ & Alasan \\
\hline \multirow[t]{3}{*}{1.} & \multirow{3}{*}{$\begin{array}{l}\text { Kegiatan } 15 \text { menit } \\
\text { membaca (membaca } \\
\text { dalam hati, membacakan } \\
\text { nyaring) yang dilakukan } \\
\text { setiap hari (di awal, } \\
\text { tengah, atau menjelang } \\
\text { akhir pelajaran) }\end{array}$} & Ada & 2 & $\begin{array}{l}\text { Dilaksanakan agar siswa memahami } \\
\text { teks. }\end{array}$ \\
\hline & & Tidak & - & \\
\hline & & Lainnya & - & \\
\hline 2. & & Ada & - & \\
\hline
\end{tabular}


Shintia Dwi Alika, Veni Nurpadillah, \& Kurnia Dewi Nurfadilah / AL-TARBIYAH, Vol. 29 No. 1, Desember 2019, 45-60

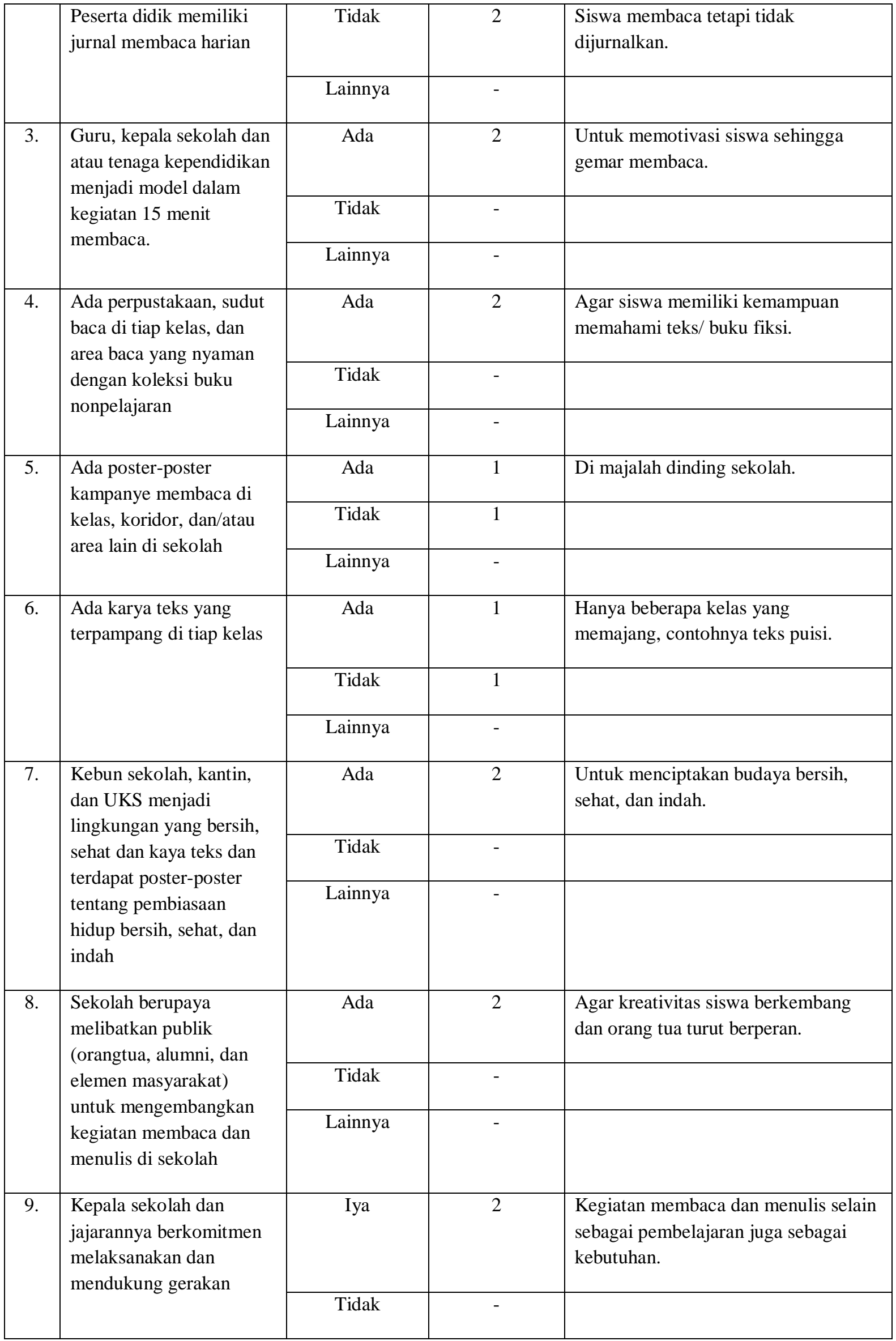




\begin{tabular}{|c|c|c|c|c|}
\hline & $\begin{array}{l}\text { membaca dan menulis di } \\
\text { sekolah }\end{array}$ & Lainnya & - & \\
\hline \multirow[t]{3}{*}{10.} & \multirow{3}{*}{$\begin{array}{l}\text { Ada kegiatan akademik } \\
\text { yang mendukung budaya } \\
\text { membaca dan menulis di } \\
\text { sekolah, misalnya: wisata } \\
\text { ke perpustakaan atau } \\
\text { kunjungan perpustakaan } \\
\text { keliling ke sekolah dan } \\
\text { mengadakan lomba } \\
\text { kepenulisan }\end{array}$} & Ada & 2 & $\begin{array}{l}\text { Siswa terukur kemampuannya dalam } \\
\text { lingkungan akademik. }\end{array}$ \\
\hline & & Tidak & - & \\
\hline & & Lainnya & - & \\
\hline \multirow[t]{3}{*}{11.} & \multirow{3}{*}{$\begin{array}{l}\text { Ada kegiatan perayaan } \\
\text { hari-hari tertentu } \\
\text { (Misalnya Bulan Bahasa) } \\
\text { yang bertemakan literasi } \\
\text { (membaca dan menulis) }\end{array}$} & Ada & 2 & $\begin{array}{l}\text { Lomba menulis cerpen dan membaca } \\
\text { puisi. }\end{array}$ \\
\hline & & Tidak & - & \\
\hline & & Lainnya & - & \\
\hline \multirow[t]{3}{*}{12.} & \multirow{3}{*}{$\begin{array}{l}\text { Ada Tim Literasi Sekolah } \\
\text { yang dibentuk oleh } \\
\text { kepala sekolah dan terdiri } \\
\text { atas guru bahasa, guru } \\
\text { mata pelajaran lain, dan } \\
\text { tenaga kependidikan }\end{array}$} & Ada & - & \\
\hline & & Tidak & 2 & Belum terprogram. \\
\hline & & Lainnya & - & \\
\hline
\end{tabular}

Berdasarkan tabel tersebut, guru siswa mengemukakan bahwa kegiatan membaca 15 menit sudah berjalan, yaitu melakukan kegiatan membaca buku teks pelajaran yang sedang dipelajari selama 15 menit. Kegiatan membaca tersebut dimaksudkan agar siswa lebih mamahami materi yang sedang dipelajari. Kemudian siswa juga tidak memiliki jurnal harian, karena biasannya hasil karya siswa hanya dikumpulkan sebagai tugas sekolah. Berdasarkan jawaban guru, terbukti bahwa pihak sekolah yaitu guru, karyawan, dan kepala sekolah terlibat dalam kegiatan literasi dengan ikut membaca buku agar siswa lebih termotivasi untuk membaca karena bersama-sama dengan warga sekolah dan memberikan pelajaran bahwa guru maupun kepala sekolah juga perlu dan wajib untuk membaca. Hal tersebut juga didukung oleh ketersediaannya perpustakaan, sudut baca di tiap kelas, dan area baca yang nyaman dengan koleksi buku nonpelajaran.

Kampanye mengenai gerakan membaca dan menulis juga ada di majalah dinding sekolah. Selain itu menurut guru yang mengajar di jurusan IPS ada karya siswa yang terpampang disetiap kelas, sedangkan di kelas IPA tidak ada. Selain itu juga terpampang poster-poster mengenai menjaga kebersihan lingkungan sekolah. Selain membudayakan membaca bagi siswa, juga sebagai suatu bentuk ajakan kepada siswa untuk menjaga kebersihan di sekolah.

Menurut kedua guru Bahasa Indonesia peran orangtua, alumni, dan elemen masyarakat juga penting dalam mengembangkan budaya membaca dan menulis. Dengan semua pihak turut membudayakan gerakan membaca selama 
15 menit, itu dapat memotivasi siswa. Kemudian kepala sekolah beserta jajarannya juga turut membudayakan kegiatan membaca dan menulis, karena kegiatan membaca dan menulis selain sebagai pembelajaran juga sebagai kebutuhan.

Di SMAN 2 Slawi ini juga ada kegiatan kunjungan ke perpustakaan, kegiatan tersebut biasanya dilaksanakan dalam proses pembelajaran bahasa Indonesia. Untuk mendukung gerakan membaca dan menulis tersebut, sekolah juga mengadakan lomba-lomba, seperti lomba menulis cerpen dan membaca puisi. Kegiatan tersebut dilaksanakan setiap ada perayaan tertentu.

Akan tetapi sampai saat ini, belum ada tim khusus untuk membudayakan gerakan literasi sekolah. Guru-guru hanya berusaha untuk membudayakan gerakan membaca dan menulis seperti biasanya, sesuai dengan kegiatan yang telah dilaksanakan sebelum-sebelumnya.

Dengan demikian, SMAN 2 Slawi belum melaksanakan gerakan literasi sekolah. Akan tetapi, seluruh pihak sekolah sudah berusaha untuk membudayakan gerakan membaca dan menulis dalam proses pembelajaran, melalui kampanye di poster-poster, dan lomba-lomba di acara perayaan tertentu.

\section{SIMPULAN}

Berdasarkan hasil observasi di SMA Negeri 2 Slawi, sekolah tersebut belum melaksanakan kegiatan literasi sekolah. Karena tidak semua siswa dan gurunya mengetahui gerakan tersebut. Akan tetapi minat membaca dan menulis siswanya sudah cukup baik. Selain itu, upaya yang dilakukan guru khususnya guru bahasa Indonesia dalam melaksanakan kegiatan budaya literasi di sekolah sudah bagus.
Begitu pula dengan upaya pihak sekolah, dengan menambah koleksi buku bacaan di perpustakaan turut mendukung gerakan literasi di sekolah.

\section{Ucapan Terima Kasih}

Ucapan terima kasih disampaikan kepada guru Bahasa Indonesia dan siswa siswi SMA Negeri 2 Slawi yang telah menjadi mitra penelitian dan telah membantu untuk proses pengumpulan data.

\section{DAFTAR PUSTAKA}

Ambigapati. (1999). Literasi dan Pengajaran. Penang: USM.

Anderson, L. W. \& Krathwohl, D. R. (2001). A Taxonomy for Learning, Teaching, and Assesing; A revision of Bloom's Taxonomy of Education Objectives. New York: Addison Wesley Lonman Inc.

Moleong, L. J. (2007). Metodologi Penelitian Kualitatif. Bandung: Remadja Karya.

Firdaus, Y. (2004). "Sebuah Kemajuan Literasi di Indonesia". Dalam http://yulian.firdaus.or.id. Diakses pada tanggal 2 Juni 2016.

Kern, R. (2000). Literacy \& Language Teaching. Oxford: Oxford University Press.

Lerner, T. C., (1988). Learning Disabilities: Theories, Diagnosis, and Teaching Strategies. Boston: Huoghton Mufflin.

De Beer, M. \& Mason, R. B. (2009). Using A Blended Approach to Postgraduate Supervision. London. May. 2009. Vol. 46. Iss. 2. pp. 213226.

Purwanto, W. E. (2007)."Menghidupi Tradisi Literasi: Problematika bagi siswa, guru, sekolah dan Negara", dalam 
http//www.titikoma.com/esai.

Diakses pada tanggal 11 November 2008

Sugiyono. (2010). Metode Penelitian

Pendidikan: Pendekatan

Kuantitatif, Kualitatif, dan $R \& D$. Bandung: Alfabeta.

Tanzeh, A. (2011). Metodologi Penelitian Praktis. Yogyakarta: Teras.

Tarwotjo. (1994). Etnografi (suatu tantangan penelitian kualitatif). Jakarta: Balai Pustaka.

Ulfatin, Nurul. (2015). Metode Penelitian Kualitatif di Bidang Pendidikan:
Teori dan Aplikasisnya. Malang: Media Nusa Creative.

Wells, B. (1987). Apprenticeshipnin Literacy. Dalam Interchange 18, 1/2:109-123.

Wulansari, D. (2011). "Kultur Literasi Mahasiswa: Suara Merdeka.Semarang, Jawa http://www.suaramerdeka.com/v1/i ndex.php/read/cetak/2011/03/12/13 9673/Kultur-Literasi-Mahasiswa [diakses di Cianjur, Indonesia: 9 Agustus 2013] 